Вісник Національного університету “Львівська політехніка”. Серія "Проблеми економіки та управління"

T. 4, № 1, 2020

UDC 339.144

JEL Classification Code M 11

V. Ya. Havran, Kh. P. Danylkiv, M. I. Havran Lviv Polytechnic National University

\title{
IMPROVING RECEIVABLES MANAGEMENT OF THE ENTERPRISE IN THE CONTEXT OF NEW CHALLENGING MARKET CONDITIONS
}

https://doi.org/10.23939/semi2020.01.151

(c) Havran V. Ya., Danylkiv Kh. P., Havran M. I., 2020

The article analyzes methods and measures of improving the enterprise's receivables management. Under new challenging market conditions, the formation of an effective receivables management system directly affects the stable and efficient enterprise's activities. The authors found out that receivables have positive and negative influence on enterprise's activities, among positive ones there are stimulating sales growth, establishing stable and longterm contacts with customer, forming competitive product range and others. The negative influence of receivables on enterprise's activities is due to the following factors: withdrawing funds from turnover, extra-expenses for managing receivables; the risk of non-return, losses caused by inflation and decrease in profit.

The expediency of applying not only quantitative but also qualitative analysis of indicators of estimating receivables current state for improving financial condition is substantiated. It is proposed the schematic sequence of the receivable analysis process which includes 5 stages divided according to the set tasks with methods and measures of their decisions.

Applying the qualitative method of $\mathrm{ABC}$ - and $\mathrm{XYZ}$-analysis, the authors arrange group of goods and services that cause receivables of Komunpostach LLC according to the main clients. Assortment groups of products with the highest, medium and low shares of receivables are classified into A, B, C groups, within which strategically important customers, customers who use services seasonally, and small customers who irregularly use services of Komunpostach LLC with poor forecasting accuracy are singled out. Having combined ABC- and XYZ-analysis, the matrix of nine groups of debtors is also formed that requires the development of its managing techniques in terms of receivables share in its total amount at the enterprise, as well as the accuracy of forecasting its dynamics.

As a result, the main measures for the effective receivables management are identified, among them: rating of customer creditworthiness; determining the criteria and peculiarities for granting a commodity loan, and also types of goods and offered services that are most likely to be owed; planning measures of receivables optimizing; establishing interdependence of the staff motivation system and the receivables value, and also outcome-based motivation principles; applying other current methods of managing receivables, such as factoring, financial risks insurance, using payment in promissory notes, etc. These measures will 
facilitate reducing the risk level of not receiving funds from enterprise's debtors and will directly increase the level of its production and economic activities profitability.

Keywords: receivables management, $\mathrm{ABC}$ - and $\mathrm{XYZ}$-analysis, assortment groups, accounts receivable, financial condition.

\section{Statement of the problem}

In the context of market economy, considerable attention is paid to the concepts of receivables and payables for the effective implementation of production and business activities. Under challenging market conditions, one of the main issues is untimed and incomplete fulfillment of obligations by entities, that is, breach of agreements between the parties, first of all, regarding the terms of payment and delivery of goods and services.

The settlement transactions are the basis of enterprise financial and business activities, which, on the one hand, cause accounts receivable, and on the other hand - payables, that in turn adversely affects activities of the entity. Therefore, market relations entities need to have effective management of receivables and payables, contributing to their constant reduction. The implementation of all necessary measures to their effective management requires a clear understanding of the nature of the above mentioned concepts.

As a result of the reduction of business operations efficiency due to increasing of the environmental factors instability, the payables and receivables structure may be disturbed and adversely affect the financial position, stability and solvency. Due to this, it is necessary to improve their management system and enhance effective analysis.

Thus, the payables and receivables study aimed at finding more effective ways of their forming and using is relevant today.

\section{Analysis of recent research and publications}

Problems of receivables management are studied and analyzed in many scientific works of Ukrainian scientists, among them R. Honcharuk, V. Novodvorska and O. Dyachuk, S. Kovtun, N. Tkachuk, I. Novakivskyi, N. Matytsyna, O. Karyy, Z. Urusova, and others. They have also made a significant contribution to the development of practical aspects of improving receivables management for its effective realization at enterprises. The procedure for forming a receivables management system in providing effective activity of the enterprise is studied in the research paper of A. Hlushko [1].

However, despite the considerable attention of the scientists, today, the problem of effective payables and receivables management remains one of the most important for ensuring the activity of enterprises. The review of scientific works shows that there is a lack of analysis and resolving of crucially important issues related to the formation of an effective policy of payables and receivables management, considering the specifics of enterprises that provide basic goods and services for utility sector.

\section{The formulation of objectives}

The aim of the study is to thoroughly analyze the effect of receivables on the business activities of entities under new challenging market conditions and to provide specific recommendations for their effective use in the activities of Komunpostach LLC.

\section{Presentation of main materials}

In different theories and scientific works of Ukrainian scientists, the main reason for establishing an effective receivables management is providing of ongoing process of enterprise's work as accounts receivables indirectly effect on enterprise's profitability and liquidity [2; 3]. Having analyzed publications of R. Honcharuk, V. Novodvorska and O. Dyachuk [3; 4], we found out that receivables have positive and negative influence on enterprise's activities, among positive ones there are stimulating sales growth, establishing stable and long-term contacts with customer, forming competitive product range and others. The negative influence of receivables on enterprise's activities is due to the following factors: withdrawing funds from turnover, extra-expenses for managing receivables; the risk of non-return, losses caused by inflation and decrease in profit, etc. 


\section{Improving receivables management of the enterprise in the context of new challenging market conditions}

Generally speaking, receivables and payables management is a process of developing and implementing management decisions regarding the consistency of their size and velocity, providing the necessary profit and the optimum amount of available funds.

Having analyzed results of the research works of R. Honcharuk and N. Matytsyna [3; 5], we found out that model of receivables management includes some elements such as: 1) static analysis of financial information on an entity's accounts receivable, interpretation of the key financial indicators and ratios meanings used for such analysis; 2) dynamic (trend) analysis and assessment of trends in the situation with the repayment of accounts receivable by counterparties; 3) justification of the optimal period for giving deferment of paying accounts by customers; 4) refinancing of enterprise's receivables (use bills accounting, factoring and forfeiting of enterprise's debt claims to third parties to cover the current need for capital); 5) control of overdue receivables and prevention of bad debts formation, etc.

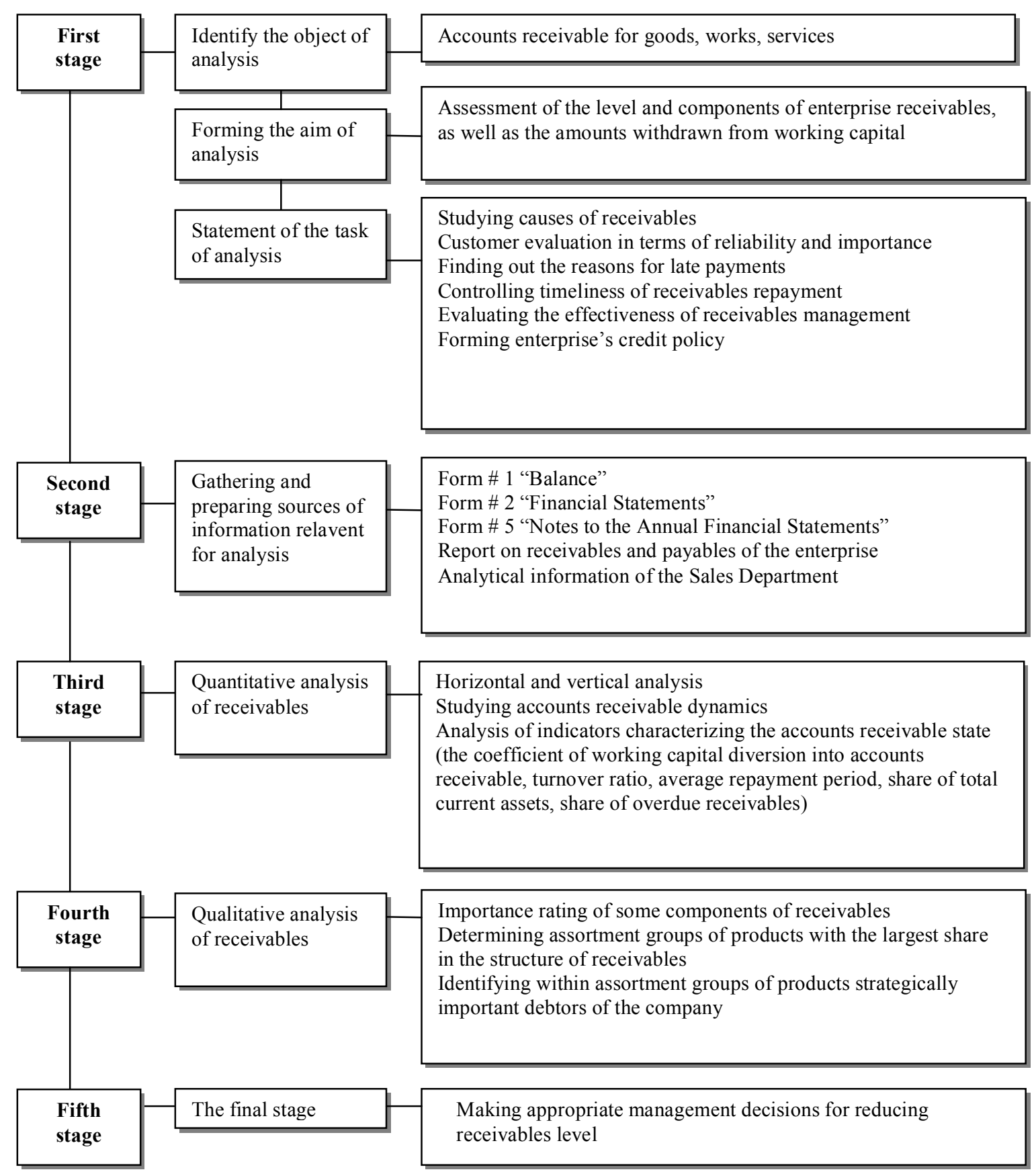

Proposed sequence of Komunpostach LLC receivables analysis 


\section{Ya. Havran, Kh. P. Danylkiv, M. I. Havran}

The periodization of liabilities and debt claims facilitate managing of settlement processes. Therefore, it is important for internal users to analyze receivables by time of their occurrence that will make it possible to identify and ensure actions in time to write off overdue receivables amount.

The analysis of payments with buyers and customers by payment arrears terms and maturity data allows determining the effectiveness of the enterprise in terms of providing discounts and loans. The receivable grouping is of practical value for enterprises, as it greatly simplifies the procedure of taking inventory of the accounts receivable state.

The practical experience of managing enterprises under uncertain conditions confirms that to ensure the efficiency of the respective processes it is not enough to carry out only quantitative analysis of evaluative indicators of the accounts receivable current state. In order to resolve this issue, the qualitative analysis should also be applied, the main task of which is to identify the types of products that cause the highest receivables for goods, works, and services.

Due to the above mentioned, it is possible to identify the most valuable customers of the enterprise (for example, major suppliers, intermediaries, consumers and other market infrastructure entities), the main types of products that mostly cause receivables. The process of receivables analysis is schematically presented at Figure. It includes 5 stages divided according to the set tasks with methods and measures of their decisions.

In order to perform given tasks, we suggest using qualitative ABC- and XYZ-analysis. In the table 1, there are services of Komunpostach LLC divided into product groups causing receivables. Assortment groups of products with the highest share of receivables are classified in group A, with medium share - in group B, with low share - in group C. Within these groups we single out strategically important customers (group X), customers who use services seasonally (group Y), small customers who irregularly use services of Komunpostach LLC with poor forecasting accuracy (group Z).

Having combined ABC- and XYZ-analysis, we singled out nine groups presented in the matrix (Table 2). Each of the groups requires the development of its management technology by indicators of the receivables share in its total amount at the enterprise, as well as the accuracy of forecasting its dynamics.

Considering the result of complex ABC- and XYZ-analysis, we identify the main and the most important resources of the enterprise and on this basis we set priorities in the structuring of business processes. The AX, AY and AZ groups require the greatest attention, careful planning of requirements, daily accounting and control, constant analysis of deviations from the planned indicators. Moreover, for the category AX, it is necessary to calculate the optimal size of deliveries, and for the category AZ, it is more efficient to use the supply system on demand, with the obligatory calculation of insurance stock amount. Generalized planning methods are used for CX, CY, and CZ resources category.

The research results show that in order to effectively manage receivables, the enterprise should comply with the following measures:

1. Carry out preliminary checking of customers in terms of their abilities to timely repayment of debts.

2. Form a rating of customer creditworthiness and to refuse from further cooperation with low credit rating customers. While forming rating it is worth taking into account such factors as the total term of cooperation with customer, the average monthly sales or cost of services provided, customer's receivables turnover rate, the amounts and terms of the overdue receivables, the assessment of the customer's importance for the enterprise.

3. Determine the criteria for granting a commodity loan, its marginal amount, terms of delaying the debt repayment, the amount and procedure for granting discounts, and penalties form.

4. Classify receivables in terms of various categories (by debtors, payment arrears terms and maturity data, reasons of receivables) in order to establish a major customers group that provide the company with the highest profits and whose losing is undesirable. Identify the groups of defaulters who are urgently required to repay their debts and identify the types of products or services that are most likely to be owed. 
Table 1

\section{ABC- and XYZ-analysis of Komunpostach LLC receivables}

\begin{tabular}{|c|c|c|c|c|}
\hline No & $\begin{array}{c}\text { Assortment groups according to the major } \\
\text { customers }\end{array}$ & $\begin{array}{l}\text { Share of } \\
\text { receivables in its } \\
\text { total amount, \% }\end{array}$ & $\begin{array}{l}\text { Product } \\
\text { group class }\end{array}$ & $\begin{array}{l}\text { Customer classification } \\
\text { based on the level of } \\
\text { sales sustainability and } \\
\text { debtor's importance }\end{array}$ \\
\hline 1 & 2 & 3 & 4 & 5 \\
\hline \multirow{4}{*}{1} & $\begin{array}{l}\text { Performing construction and installing, repair, } \\
\text { construction and contracting works }\end{array}$ & 30.30 & Group A & \\
\hline & Budimeks LLC & & & Group X \\
\hline & Lviv Balaton-409 Utility & & & Group Z \\
\hline & Lviv Zamarstyniv-400 Utility & & & Group Y \\
\hline \multirow{3}{*}{2} & $\begin{array}{l}\text { Renting industrial equipment, machinery and } \\
\text { outfits }\end{array}$ & 23.70 & Group A & \\
\hline & Lviv Pid Holoskom -410 Utility & & & Group Y \\
\hline & Lviv Zboishcha - 408 Utility & & & Group Y \\
\hline \multirow{4}{*}{3} & $\begin{array}{l}\text { Construction, reconstruction and other real } \\
\text { estate activities }\end{array}$ & 15.20 & Group B & \\
\hline & Lviv Ryasne - 403 Utility & & & Group X \\
\hline & Lviv Vira Utility & & & Group Y \\
\hline & Lviv Dim Utility & & & Group Z \\
\hline \multirow{3}{*}{4} & $\begin{array}{l}\text { Repair and maintenance of industrial machinery } \\
\text { and equipment }\end{array}$ & 11.40 & Group B & \\
\hline & Stykhiya Small Enterprise & & & Group X \\
\hline & Lviv Pidzamche - 404 Utility & & & Group Y \\
\hline \multirow{4}{*}{5} & $\begin{array}{l}\text { Activities for organizing cargo transportation } \\
\text { by motor vehicles }\end{array}$ & 9.50 & Group C & \\
\hline & Lviv Varshavske - 407 Utility & & & Group X \\
\hline & Lviv Pivnichne - 411 Utility & & & Group Y \\
\hline & Aeroprokat LLC & & & Group Z \\
\hline \multirow{5}{*}{6} & $\begin{array}{l}\text { Renting, buying, hiring, selling and leasing of } \\
\text { movable and immovable property }\end{array}$ & 7.30 & Group C & \\
\hline & Lviv Ryasne - 402 Utility & & & Group Y \\
\hline & Lviv Ryasne - 403 Utility & & & Group X \\
\hline & Lviv Topolya - 406 Utility & & & Group Z \\
\hline & Lviv Utility №500 & & & Group Y \\
\hline \multirow{6}{*}{7} & Organizing parking lots & 2.60 & Group C & \\
\hline & Stykhiya Small Enterprise & & & Group X \\
\hline & Proton LLC & & & Group Z \\
\hline & Artbis LLC & & & Group Y \\
\hline & EnergiaM LLC & & & Group Y \\
\hline & Total & 100.00 & & \\
\hline
\end{tabular}

Table 2

Matrix of the combining ABC- and XYZ-analysis of Komunpostach LLC receivables results

\begin{tabular}{|l|c|c|c|}
\hline $\begin{array}{r}\text { Degree of customer importance / } \\
\text { product group }\end{array}$ & Highest & Medium & Lowest \\
$\begin{array}{l}\text { Importance of customer receivables } \\
\text { by product group: }\end{array}$ & & & \\
\hline Highest & $\mathrm{AX}$ & $\mathrm{AY}$ & $\mathrm{AZ}$ \\
\hline Medium & $\mathrm{BX}$ & $\mathrm{BY}$ & $\mathrm{BZ}$ \\
\hline Lowest & $\mathrm{CX}$ & $\mathrm{CY}$ & $\mathrm{CZ}$ \\
\hline
\end{tabular}




\section{Ya. Havran, Kh. P. Danylkiv, M. I. Havran}

5. Make a plan of measures for working with each customer by setting deadlines, responsible people, cost estimation, and also effect received.

6. Organize keeping of receivables register and distinguish overdue accounts receivable.

7. Make a real assessment of the value and speed of receivables turnover.

8. Link the staff motivation system to the receivables value, and develop and approve outcomebased motivation principles.

9. Enter information on the receivables repayment planned amounts in the enterprise's financial plan and monitor its implementation.

10. Introduce other current methods of managing receivables, such as factoring, financial risks insurance, using payment in promissory notes.

To sum up, all above mentioned measures and methods of managing receivables will facilitate reducing the risk level of not receiving funds from debtors, establishing Komunpostach LLC effective credit policy, which, in turn, will directly increase the level of production and economic activities profitability.

\section{Conclusions}

Thus, the conducted research confirms that the combined ABC- and XYZ-analysis is an effective measure for structuring the assortment groups of products and customers aimed at optimizing and ensuring the efficiency of receivables management. ABC- and XYZ-analysis being mechanisms in the information system is a competitive advantage of the enterprise and provides effective receivables management, which in turn will facilitate reducing risks of not receiving funds from debtors and establishing Komunpostach LLC effective credit policy.

\section{Prospects for further research}

The scope of this research paper is considered to be rather limited, but there are prospects for further studies as well as unresolved aspects of the given issue. One of the directions that further studies can take is to study conditions for using different forms of receivables refinancing in order to improve enterprise's financial state. On the other hand, it is important to study and analyze foreign experience in applying securitization of assets to receivables.

1. Глушко А. Д. (2018). Управління дебіторською заборгованістю в системі забезпечення ефективної діяльності підприємства // Електронне наукове видання “Ефективна економіка". № 7. Режим доступу: www.economy.nayka.com.ua.

2. Пінчук Т. А. (2014). Організаційно-методичні проблеми обліку дебіторської заборгованості в системі управління підприємством // Ефективна економіка. № 10. С. 36-41.

3. Гончарук Р. П. (2015). Сутність та класифікація кредиторської заборгованості: колізії наукових підходів // Вісник Житомирського державного технологічного університету. Серія: Економічні науки. №. 1(59), Ч. 1.

4. Дячук О. В., Новодворська В. В. (2013). Місце кредиторської заборгованості в системі управління підприємством // Економічні науки. Сер.: Облік і фінанси. Вип. Т. 10. №. 3. С. 243-251.

5. Матицина Н. О. (2015). Основні засади регулювання розрахункових відносин через управління дебіторською заборгованістю / Н.О. Матицина // Бухгалтерський облік і аудит. № 12. С. 38-42.

6. Novakivskyi I., Karyy O. (2018). Transformation of company management systems in the context of the formation of an information society. P. 8-26 [in] Innovation Process Management in Ukraine: problems in commercialization of scientific and technical developments: Monograph / Yurii Vovk, Oleh Karyy, Ihor Kulyniak, Yosyf Petrovych, and other / Edited by Yurii Vovk, Oleh Karyy. Lviv : LLC "Rastr-7". 266 p.

7. Гуня В. О. (2014). Удосконалення класифікації дебіторської заборгованості та ії відображення у фінансовій звіт- ності підприємств // Економічний простір. № 19. С. 124-131. 
Improving receivables management of the enterprise in the context of new challenging market conditions

8. Урусова 3. П., Вороніна М. І. (2016). Внутрішній контроль дебіторської заборгованості: шляхи вдосконалення та вирішення проблем // Вісник Запорізького національного університету. Економічні науки. No. 2. C. 121-125.

1. Hlushko A. D. (2018). Upravlinnia debitorskoiu zaborhovanistiu v systemi zabezpechennia efektyvnoi diialnosti pidpryiemstva [Management of accounts receivable in the system of provision of effective activity of the enterprise]. Electronic scientific issue "Efectyvna ekonomika" [Effective Economy]. No. 7. URL: www.economy.nayka.com.ua. [in Ukrainian].

2. Pinchuk T. A. (2014). Orhanizatsiino-metodychni problemy obliku debitorskoi zaborhovanosti v systemi upravlinnia pidpryiemstvom [Organizational and methodical problems of receivables accounting in the enterprise management system]. Efectyvna ekonomika [Effective Economy]. No. 10. P. 36-41. [in Ukrainian].

3. Honcharuk R. P. (2015). Sutnist ta klasyfikatsiia kredytorskoi zaborhovanosti: kolizii naukovykh pidkhodiv [The nature and classification of payables: conflicts of scientific approaches]. Visnyk Zhytomyrskoho derzhavnoho tekhnolohichnoho universytetu Ekonomichni nauky [Economic Sciences]. No. 1(59), Part 1. [in Ukrainian].

4. Diachuk O. V., Novodvorska V. V. (2013). Mistse kredytorskoi zaborhovanosti v systemi upravlinnia pidpryiemstvom [The role of payables in the enterprise management system]. Ekonomichni nauky [Economic Science]. Series Accounting and Finance. Issue10. No.. 3. P. 243-251. [in Ukrainian].

5. Matytsyna N. O. (2015). Osnovni zasady rehuliuvannia rozrakhunkovykh vidnosyn cherez upravlinnia debitorskoiu zaborhovanistiu [The basic principles of regulating settlement relations through receivables management]. Bukhhalterskyi oblik $i$ audyt [Accounting and Audit]. No. 12. P. 38-42. [in Ukrainian].

6. Novakivskyi I., Karyy O. (2018). Transformation of company management systems in the context of the formation of an information society. Monograph. Innovation Process Management in Ukraine: problems in commercialization of scientific and technical developments. Edited by Yurii Vovk, Oleh Karyy. Lviv: LLC "Rastr-7". P. 8-26.

7. Hunia V. O. (2014). Udoskonalennia klasyfikatsii debitorskoi zaborhovanosti ta yii vidobrazhennia u finansovii zvit nosti pidpryiemstv [Improving receivables classisfication and its reflecting in eneterprises' financial statements]. Ekonomichnyi prostir [Economic space]. No. 19. P. 124-131. [in Ukrainian].

8. Urusova Z. P., Voronina M. I. (2016). Vnutrishnii kontrol debitorskoi zaborhovanosti:shliakhy vdoskonalennia ta vyrishennia problem [Internal accounts receivable control: ways to improve and solve problems] Внутрішній контроль дебіторської заборгованості:шляхи вдосконалення та вирішення проблем]. Visnyk Zaporizkoho natsionalnoho universytetu. Ekonomichni nauky [Economic Sciences]. No. 2. P. 121-125. [in Ukrainian].

В. Я. Гавран, Х. П.Данилків, М. І. Гавран Національний університет “Львівська політехніка"

\section{УДОСКОНАЛЕННЯ УПРАВЛІННЯ ДЕБІТОРСЬКОЮ ЗАБОРГОВАНІСТЮ ПІДПРИЄМСТВА В КОНТЕКСТІ НОВИХ РИНКОВИХ ВИКЛИКІВ}

(С) Гавран В. Я., Данилків Х. П., Гавран М. I., 2020

Проаналізовано способи та засоби удосконалення управління дебіторською заборгованістю на підприсмствах. В складних ринкових умовах та нових викликів формування ефективної системи управління дебіторською заборгованістю безпосередньо впливає на стабільну та ефективну діяльність підприємства. Обгрунтовано доцільність застосування не лише кількісного, але й якісного аналізу показників оцінки поточного стану дебіторської заборгованості 3 метою покращення фінансового стану і рівня платоспроможності підприсмства. Запропоновано послідовність процесу аналізу дебіторської заборгованості, який складається із сукупності завдань та методів їх вирішення, згрупованих у п'ять етапів.

Застосовуючи якісний метод АBC- та XYZ-аналізу, проведено групування послуг та товарів, за якими виникас дебіторська заборгованість ТОВ «Комунпостач» відповідно до основних кліснтів. Представлено матрицю об'сднаних результатів АВС- та XYZ-аналізу, де виокремлено дев'ять груп дебіторів, кожна 3 яких потребує розроблення своєї технології управління за 


\section{Ya. Havran, Kh. P. Danylkiv, M. I. Havran}

показниками частки дебіторської заборгованості в загальній її сумі на підприємстві, а також точності прогнозування ії динаміки.

Результатом проведеного дослідження стало визначення основних заходів для ефективного управління дебіторською заборгованістю підприємства, серед яких виокремлено: рейтингування кредитоспроможності кліснтів; визначення критеріїв та особливостей надання товарного кредиту, а також видів продукції чи запропонованих послуг, за якими найбільш імовірне виникнення заборгованості; планування заходів щодо оптимізації дебіторської заборгованості; встановлення взаємозалежності системи мотивації персоналу із розміром дебіторської заборгованості, а також досягнутими результатами; запровадження сучасних методів управління дебіторською заборгованістю, серед яких факторинг, страхування фінансових ризиків, використання оплати векселями тощо.

Ключові слова: управління дебіторською заборгованістю, АВС- та XYZ-аналіз, асортиментні групи, дебіторська заборгованість, фінансовий стан. 